\title{
PREROGATIVE POWERS: NEW LABOUR'S \\ FORGOTTEN CONSTITUTIONAL REFORM?
}

\section{Keith Syrett*}

Described by one of its chief architects as "the most ambitious and extensive programme of constitutional reform and modernisation this century", ${ }^{1}$ the Labour government"s proposed package of constitutional change has prompted much debate among public lawyers ${ }^{2}$ and political commentators alike ${ }^{3}$. Yet, while the new government ostensibly seeks to "renew our politics" and criticises the retention of "traditions well after they have outlived any useful purpose", 4 its ministers continue to conduct important affairs of state by means of prerogative powers derived from those possessed by the monarchy prior to the constitutional settlement of 1688 .

This article explores the themes underpinning the constitutional programme of "New Labour", evaluating their compatibility with the royal prerogative. In the light of an apparent unwillingness on the part of the executive to instigate reform in this context, the potential of Parliament and the courts to "modernise" the prerogative is examined; and finally, methods by which such reform could be effected - should the political will exist - are analysed.

\section{Prerogative powers and the "Blairite constitution"}

The programme of constitutional reform launched by the Labour government has attracted some criticism from those who, while in sympathy with the changes

"Lechurer, Norwich Law School, University of East Anglia. I am deeply indebted to Liz Barham both for her invaluable research and for the many lively discussions we have had on this topic. All errors, however, remain my sole responsibility.

${ }^{\mathrm{L}}$ Lord Irvine of Lairg L.C., Opening Address to Conference on Constitutional Reform in the UK, Cambridge (17 January 1998).

${ }^{2}$ See University of Cambridge Centre for Public Law, Constitutional Reform in the United Kingdom: Principles and Practice (1998).

${ }^{3}$ See, inter alia, A. Barnett, This Time: Our Constitutional Revolution (1997); P. Riddell, Parliament Under Pressure (1998), Chapter 5.

${ }^{4}$ Labour Party, New Labour New Life for Britain (1996), pp.3, 31. 
overall, point to the absence of a coherent statement of underlying philosophy and ultimate objectives. ${ }^{5}$ Accordingly, it is difficult to identify a distinctive New Labour theory of the state which might be of assistance to public lawyers in evaluating the appropriateness of existing institutions, processes and principles within the "new constitutional settlement" for which the Prime Minister has called. ${ }^{6}$ Nevertheless, a number of central, interlocking themes can be identified as informing New Labour thinking, discourse and policy on reform of the institutions of government; and through an analysis of these it is possible to form some conclusions on the overall shape of the "Blairite constitution".

At the very heart of the New Labour "project" lies a philosophy of modernisation. As the party's election manifesto makes clear, this is seen as a logical progression from the internal changes made under Blair's leadership, ${ }^{7}$ and it now provides a fundamental justification for key elements of the Government's programme. ${ }^{8}$ Constitutional reform - often labelled "democratic renewal" - forms an integral aspect of this, with social and economic reconstruction seen as inextricably linked to such changes. ${ }^{10}$ The objective of modernisation thus underpins a number of the reform proposals; this is perhaps most explicit in the case of changes to the House of Lords and the establishment of a Select Committee on Modernisation of the House of Commons, but is also apparent in proposals for the "renewal of local

'See A. Barnett, "Constitutional Possibilities" (1997) 68 Political Quarterly 361. The nearest equivalent to a comprehensive statement of the principles underpinning the Blair Government"s constitutional project is the Report of the Joint Consultative Committee on Constitutional Reform issued by the Labour and Liberal Democrat parties in March 1997, which interestingly recommends that "the new Government should make an early declaration setting out the principles behind its programme of constitutional reform and outlining the more open and modern democracy it seeks to create" (para. 86).

${ }^{6}$ A. Blair, speech delivered in Cardiff, 15 July 1994, quoted in Barnett, supra. n.3, p. 256.

${ }^{7}$ Labour Party, New Labour Because Britain Deserves Better (1997), p.5: "We have modernised the Labour Party and we will modernise Britain".

${ }^{8}$ See, eg, A Mayor and Assembly for London (Cm. 3897, 1998), para. 1.5: "This government was elected with a mandate to modernise Britain and bring our political and administrative arrangements up to date".

9 A. Blair, "Democracy's second age", The Economist, 14 September 1996, p.33.

${ }^{10}$ See Blair, ibid. p.35; P. Mandelson and R. Liddle, The Blair Revolution (1996), pp.1516, 192. 


\section{PREROGATIVE POWERS AND NEW LABOUR}

democratic government", ${ }^{11}$ new forms of govemment for London ${ }^{12}$ and devolution. ${ }^{13}$ Taken overall, the avowed intention is that "the programme will give the United Kingdom a modern constitution fit for the 21 st century". ${ }^{14}$

A second key principle of the constitutional programme is that of decentralisation. This is linked to the previous theme in that it rests upon a critique of the "Old Labour" belief "in the wisdom and power of the centralised state", in contrast to the view that "modernisation ... requires a new decentralised and devolved style of politics". 15 The creation of a Scottish Parliament and Welsh Assembly, renewal and innovation in local government, the establishment of a Mayor and Assembly for London and - potentially - elected regional assemblies in England ${ }^{16}$ all reflect the belief that "there is too much power centralised in the hands of too few people". ${ }^{17}$

The construction and renovation of institutions which operate at a distance from those which have traditionally governed a centralised, unitary state is symptomatic of a broader objective of democratisation. This is partially expressed, especially in the context of devolution and local government, as "moving decision-making closer to the citizen", 18 but it also entails a shift from "top-down" political machinery to a "bottom-up" approach based around wider participation, consultation and public involvement in policy-making and service delivery. Such thinking informs the use of referenda (on government for Scotland, Wales and London); the publication of

${ }^{11}$ Department of Environment, Transport and the Regions, Consultation Paper on Local Democracy and Community Leadership (1998), especially Chapter 1 .

${ }^{12}$ Supra. n.8, paras. $1.1,1.5,1.7$.

${ }^{13}$ See $A$ Voice for Wales (Cm. 3718, 1997); and especially Scotland's Parliament (Cm. $3658,1997)$, para. 4.2 .

${ }^{14}$ Scotland's Parliament, supra. n.13, para. 1.6

${ }^{15}$ Mandelson and Liddle, supra. n. 10, pp. $27,16$.

${ }^{16}$ These have evidently been ruled out for the present - see A. Gray and B. Jenkins, "New Labour, New Government? Change and Continuity in Public Administration and Government 1997" (1998) 51 Parliamentary Affairs 111 at 117.

${ }^{17}$ Joint Consultative Committee on Constitutional Reform, supra. n.5, para. 6.

${ }^{18}$ A Voice for Wales, supra. n.13, para. 3.2. 
draft legislation and greater pre-legislative scrutiny; ${ }^{19}$ new mechanisms within local government such as citizens" juries, deliberative opinion polls and standing citizens" panels, ${ }^{20}$ and the creation of a "People's Panel" to involve the public in the delivery of services and the operation of the Citizen's Charter. ${ }^{21}$ Taken together with possible electoral reform, such initiatives can be seen as pluralistic in nature, appropriate for a government which purportedly "celebrates diversity"22 and advocates the creation of "different centres of power" as a way to "release... creative and innovative energy". ${ }^{23}$ Methods by which the public can be given a voice in decision-making also form part of a theme of citizen empowerment. This is closely linked to a perception that the public has become disaffected with politics, partly because of its polarised nature, and partly because "people feel no ownership, no stake in much of the political process" since it is too remote and centralised. ${ }^{24}$ Blair has therefore called for a "stakeholder politics" 25 in which power is brought closer to people through the policies of decentralisation discussed above. Such democratic empowerment forms part of a move away from the individualistic, market-oriented philosophy associated with the Conservatives towards the creation of "a modern notion of citizenship [which] gives rights but demands obligations", ${ }^{26}$ concretely manifested by the incorporation of the European Convention on Human Rights into domestic law. It is notable that New Labour rhetoric explicitly defines the public as "citizens rather than subjects". ${ }^{27}$

A final theme, once again inextricably intertwined with each of the others, is that

${ }^{19}$ Select Committee on Modernisation of the House of Commons, First Report, The Legislative Process, H.C. 190 (1997-8), paras. 19-30.

20 Supra. n. 11, Chapter 4.

2t See Cabinet Office news release, announcing launch of "Service First" to replace Citizen's Charter programme, 30 June 1998.

${ }^{22}$ Mandelson and Liddle, supra. n. 10, p. 197.

${ }^{23}$ A. Blair, New Britain (1996), p.312.

${ }^{24}$ Idem.

${ }^{25}$ Ibid. Chapter 36.

${ }^{26}$ Ibid. p. 218.

${ }^{27}$ Mandelson and Liddle, supra. n. 10, p.210. 


\section{PREROGATIVE POWERS AND NEW LABOUR}

of accountability. ${ }^{28}$ New participatory mechanisms offer "citizens" the opportunity to hold national and local government to account, as well as articulating their views; while devolution proposals are explicitly justified as a means of "extending democratic accountability"29 and "addressing the democratic deficit" ${ }^{280}$. To these policies should be added proposed freedom of information legislation, the objective of which is stated as "to encourage more open and accountable government",31 and a manifesto promise to review ministerial accountability "so as to remove recent abuses", 32 evidently underpinned by the view that "there is little or no genuine accountability to Parliament for ministers' actions". ${ }^{33}$

It should be apparent, even from this relatively cursory analysis, that the continued existence and use of prerogative powers by government is fundamentally at odds with New Labour thinking on constitutional issues. The most striking contradiction is surely between the rhetoric and policies of "modernisation" and the antiquity of the prerogative, as the common law "residue" of powers formerly possessed by the monarchy "from the time of the Norman Conquest down to the Revolution of $1688^{134}$ It is difficult to see how a government employing a discourse of "democratic renewal", embedded within a forceful critique of the anachronism of many political institutions, ${ }^{35}$ can justify activities taken under such a source of authority.

Prerogative powers conflict with the New Labour "project" in several other respects. Originating in the monarchy, and now exercised primarily by ministers in the name of the Crown, they epitomise the "top-down" tradition which has characterised British constitutional structure, in which "real power continues to flow

${ }^{28}$ See especially Joint Consultative Committee on Constitutional Reform, supra. n.5, para. 4: "Democratic government should ensure that those who hold power in the name of the people are accountable to the collective wishes and interests of the people".

29 Supra. n. 14, para. 6.2

${ }^{30}$ Supra. n. 18, para 1.4 .

${ }^{31}$ Your Right to Know (Cm. 3818, 1997), para. I.2.

${ }^{32}$ Supra. n.7, p.33. A revised Ministerial Code was issued in July 1997.

${ }^{33}$ Mandelson and Liddle, supra. n. 10, p. 188.

${ }^{34}$ A. Dicey, Introduction to the Study of the Law of the Constitution (1885), p.421.

${ }^{35}$ See particularly Blair, supra. n.9, p.33; Mandelson and Liddle, supra. n.10, pp.183-9. 


\section{THE DENNING LAW JOURNAL}

from the top of the pyramid to its base" ${ }^{36}$ The powers are centralised in the hands of a few members of the executive (and particularly the Prime Minister) at the apex of the political system, thus violating notions of pluralism and diffusion of power. The prerogative is "democratised" only in the limited sense that most powers are vested in ministers elected every four or five years by universal franchise; there is no element of popular participation in particular activities taken under its authority hence "citizen empowerment" in this context is negligible, especially given the close connection between the prerogative and subjecthood, ${ }^{37}$ which seems inappropriate to modern notions of citizenship. ${ }^{38}$ Finally, as the next section of this article will show, accountability for the exercise of these powers is very limited, resulting in a "democratic deficit" seen by critics as highly significant because of the importance of many of the functions carried out under the authority of the prerogative. ${ }^{39}$

However, despite its evident incompatibility with New Labour thinking, reform of the royal prerogative does not currently form part of the Government's programme. ${ }^{40}$ This was confirmed by the Prime Minister himself when, in reply to a written question from a Liberal Democrat MP as to plans "to increase democratic involvement and accountability" in areas of government covered by the prerogative, he stated that "there are no plans at present to legislate on matters dealt with under the royal prerogative". ${ }^{41}$ Indeed, New Labour has already shown its willingness to use one particular prerogative power - that of management and regulation of the civil service - to political advantage, both in reversing the most controversial exercise of

${ }^{36} \mathrm{R}$. Austin, "Administrative Law's Reaction to the Changing Concepts of Public Service" in P. Leyland and T. Woods (eds.), Administrative Law Facing the Future (1997), p.9.

${ }^{37}$ See J. Chitty, A treatise on the law of the prerogatives of the Crown (1820), p.iii: "The prerogative is not the iron tie of unbridled power: it holds the subject in the silken chain of mild subjection".

${ }^{38}$ See C. Vincenzi, Crown Powers, Subjects and Citizens (1998), pp.2-3.

${ }^{39}$ For a discussion of the range of prerogative powers, see 8 Halsbury's Laws (4th ed., 1974), para. 889ff. Among the most significant and controversial are those of patronage; "keeping the Queen's peace"; defence of the realm and emergency powers; the conduct of foreign and diplomatic affairs (including treaty-making, declarations of war and peace and the issue of passports); management and regulation of the civil service; the appointment of the Prime Minister and the summoning and dissolution of Parliament; and the prerogative of mercy.

${ }^{40}$ Save where such reform is incidental to specific issues which may be addressed by legislation; for example, on the civil service - see infra. n.97 and text.

${ }^{41}$ Official Report (H.C.) 12 March 1998, vol. 307, col. WA 279. 


\section{PREROGATIVE POWERS AND NEW LABOUR}

this power by the Thatcher government, ${ }^{42}$ and in making contentious appointments of special advisors to Downing Street. ${ }^{43}$

Such a stance contrasts sharply with previous Labour pronouncements on the issue - notably the rather vague commitment in the last election manifesto to "end ministerial misuse of the Royal Prerogative", 44 the position taken by the party's National Policy Forum, ${ }^{45}$ and (perhaps most significantly from a "New Labour" standpoint) the comments of the present Home Secretary in 1994 that "the royal prerogative has no place in a modern western democracy... we should aim for a situation where all powers exercised by the executive, and by the monarch, are based upon statute". ${ }^{46}$ It seems apparent that, while the transition from "Old" to "New" Labour may have been marked by an increasing radicalism on many constitutional matters, reform of prerogative powers ${ }^{47}$ is no longer considered a subject worthy of political debate or of Parliamentary time. ${ }^{48}$

\section{Parliament and the courts: mitigating the democratic deficit?}

${ }^{42}$ By restoring the right to union membership at G.C.H.Q. - see Official Report (H.C.) 19 May 1997, vol. 294, cols. WA 13-14.

${ }^{43}$ An amendment to the Civil Service Order in Council 1982 allowed Alistair Campbell and Jonathan Powell to undertake executive responsibilities previously performed by civil servants: see Official Report (H.C.), 2 June 1997, vol. 295, col. WA 96

${ }^{44}$ Labour Party, It's time to get Britain working again (1992), p.24.

${ }^{45}$ A New Agenda for Democracy (1993).

${ }^{46} \mathrm{~J}$. Straw, "Abolish the Royal Prerogative" in A. Barnett (ed.), Power and the Throne (1994), pp. 125, 128.

${ }^{47}$ This is despite the evidence of a survey reported in the Sunday Times ("Labour MPs want debate on monarchy", 14 September 1997), which showed 39\% of Labour backbenchers in favour of reform of the prerogative.

${ }^{48}$ Most recently, the independent think-tank Demos, regarded as influential upon New Labour thinking and policy, has proposed a depoliticisation of the monarchy. As part of such reform, a Monarchy Act would be passed, transferring residual political powers away from the monarchy to a number of other institutions: see T. Hames and $M$. Leonard, Modernising the Monarchy (1998), pp. 23-6. The Demos proposals focus upon those areas in which the monarch continues to have a personal role in constitutional matters, rather than the wider issue of executive actions taken under the authority of the prerogative; nevertheless, it is worthy of note that the government has sought to distance itself from them - see "Blairite group seeks vote on Do we want King Charles?", The Times, 7 September 1998. 
It appears, therefore, that there is a substantial contradiction between the continued existence and exercise of ministerial powers derived from the royal prerogative and many of the central principles underpinning Labour's constitutional project; yet reform of this area of the constitution does not presently seem to form part of the Government's plans. In view of the executive's reluctance or unwillingness to act in this area, it may be asked whether either of the other branches of government, as presently constituted, are capable of responding to the usage of prerogative powers in a manner which might render them more compatible with the modernised constitutional settlement seemingly envisaged by the Blair administration.

\section{(a) Parliament}

Parliamentary oversight of the exercise of prerogative power is limited by a number of factors. The effectiveness of scrutiny of prerogative action - as with all other exercises of ministerial authority - is severely constrained by party loyalty, enforced through the whip system. Individual ministerial responsibility for decisions made under statute or the prerogative has been described as containing elements of "ambiguity and confusion", 4 with the ultimate sanction of resignation only enforced when the support of the Prime Minister and parliamentary colleagues is lost; while answerability to Parliament is circumscribed by ministerial control over information which enables a selective account of decisions and events to be constructed, despite the provisions of the Ministerial Code. ${ }^{50}$ These weaknesses are exacerbated by the lack of time available for debates and questions both on the floor of the House and in Select Committee.

These are familiar criticisms of Parliament's inability to hold the executive to account. However, the role of the legislature in respect of prerogative powers is even more heavily circumscribed than the foregoing discussion suggests. Many of the functions performed by government under the authority of the prerogative, such as matters relating to defence of the realm and international diplomacy, are politically sensitive by their very nature and are accordingly unlikely to be the subjects of full account in Parliament. Moreover, Erskine May lists a number of

${ }^{49}$ Public Service Committee of the House of Commons, Ministerial Accountability and Responsibility, HC 313-I (1995-6), para. 2.

${ }^{50}$ The obligation of ministers to provide full and accurate information to Parliament lay, of course, at the heart of the Scott Inquiry: see A. Tomkins, "Government Information and Parliament: Misleading by Design or by Default?" [1996] P.L..472. 


\section{PREROGATIVE POWERS AND NEW LABOUR}

topics falling within the prerogative, upon which, by convention, questions may not be raised. ${ }^{s t}$ The result of this is that disclosure of information on the exercise of prerogative powers may be minimal. $^{52}$

Parliament is, therefore, severely constrained in its ability to become involved in the exercise of prerogative powers. Such weakness is, of course, highly advantageous to government and provides an incentive to utilise prerogative, as opposed to statutory powers, since they will be subject to reduced scrutiny, both before and after the decision or action. ${ }^{53}$ For its part, however, there seems to be little prospect of the legislature taking the initiative to "democratise" the prerogative. In the absence of government support, the opportunities for backbench MPs to initiate legislation to curtail the prerogative are scarce and the chances of success almost nil $;{ }^{54}$ while it is undoubtedly significant that the most recent Commons debate on the general use of prerogative powers took place on an adjournment motion at 2:20am. ${ }^{55}$ Furthermore, although there have been calls for investigation of the prerogative by Select Committee, ${ }^{56}$ no such action has been taken ${ }^{57}$ - moreover, it is questionable whether any such review is likely to be wholly effective, especially given the government's ability to control the release of information. ${ }^{58}$ All that

\section{${ }^{51}$ Parliamentary Practice (21 st ed., ed. C. Boulton, 1989), p.288.}

52 See a Parliamentary statement by the former Prime Minister: "it is for individual Ministers to decide on a particular occasion whether and how to report to Parliament on the exercise of prerogative powers": Official Report (H.C.) l March 1993, vol. 220, col. WA 19.

53 See A. LeSeuer and M. Sunkin, Public Law (1997), p. 270. Such an analysis is, unsurprisingly, not shared by those in ministerial office - see Official Report (H.C.) 21 April 1993, vol. 223 , cols. $487-492$.

${ }^{34}$ See the discussion of the Commonwealth of Britain Bill, infra. n. 86 and text.

${ }^{55}$ Official Report (H.C.) 21 April 1993, vol. 223, cols. 485-492

${ }^{56} \mathrm{Ibid}$. col. 487 .

${ }^{57}$ It is unclear whether issues relating to the prerogative will fall within the purview of the new Select Committee on the Modernisation of the House of Commons. During the debate upon its inception, it was stated merely that the Committee would examine the means by which Ministers were held to account: Official Report (H.C.) 22 May 1997, vol. 294, col. 907.

${ }^{58}$ Particularly pertinent in this context is the Select Committee investigation into the banning of trade unions at G.C.H.Q. The government refused to permit the director of G.C.H.Q. and a union representative to give evidence - see Employment Committee, First Report, HC 238 (1983-4), paras. 6-7; and further LeSeuer and Sunkin, supra. n.53, Chapter 17. 
Parliament can realistically achieve, given the dominance of an executive anxious to retain and use its prerogative powers, is a very weak form of scrutiny of actions taken under the authority of the prerogative once they have already occurred.

\section{(b) The courts}

In recent years, the courts have shown a willingness to subject the exercise of prerogative powers to increased judicial oversight. The G.C.H.Q. case $^{59}$ established that decisions taken under the authority of the prerogative were in principle reviewable upon the same basis as those made by virtue of statute; and in a number of subsequent cases, the courts have been prepared to investigate the manner in which prerogative powers are exercised. ${ }^{60}$ The crucial factor now determining whether a governmental decision or action is reviewable is not the source of the power - there is no "logical reason why the fact that the source of the power is the prerogative and not statute should today deprive the citizen of that right of challenge to the manner of its exercise which he would possess were the source of the power statutory"; 61 but whether the subject matter involved is of such nature as to be justiciable. $^{62}$

In expanding the reach of judicial review to cover the manner of exercise of the prerogative, the courts may be seen to be demonstrating an awareness of the necessity to modernise and render properly accountable this source of executive power - for example, in the G.C.H.Q. case, Lord Roskill expressed concern that the development of administrative law might be hampered by "harking back to... the clanking of medieval ghosts of the past" and criticised the "source" test of reviewability on the basis that both statutory and prerogative actions were executive acts and therefore that "to talk of that act as the act of the sovereign savours of the

${ }^{59}$ Council of Cinil Service Unions v Minister for the Civil Service [1985] A.C. 374.

${ }^{60}$ E.g. $R v$ Secretary of State for Foreign and Commonwealth Affairs, ex parte Everett [1989] QB 811; R v Secretary of State for the Home Department, ex parte Bentley [1994] QB 349; $R v$ Criminal Injuries Compensation Board, ex parte $P$ [1995] 1 All E.R. 870; $R v$ Ministry of Defence, ex parte Smith [1996] 1 All E.R. 257 (C.A.). For a discussion of the role of the courts in this area, see D. Pollard, "Judicial Review of the Prerogative in the United Kingdom and France" in Leyland and Woods, stupra. n.36, pp.297-309.

${ }^{61}$ Lord Roskill, supra. n.59 at 417.

${ }^{62}$ Lord Scarman, ibid. at 407. 


\section{PREROGATIVE POWERS AND NEW LABOUR}

archaism of past centuries". ${ }^{63}$

The growth of judicial activism in this context is also underpinned by a general perception of the inadequacies of Parliament as a check upon the executive, characterised by the present Lord Chancellor's extra-judicial statement that "the consequences of the "democratic deficit"... have been, to an important degree, mitigated by the rigours of judicial review", ${ }^{4}$ and echoed by several other senior members of the judiciary ${ }^{65}$ and academic commentators. ${ }^{66}$ In the specific case of prerogative powers, the clearest exposition of a role for the courts in compensating for the shortcomings of Parliament appears in the dissenting judgment of Lord Mustill in the Fire Brigades Union case:

"In recent years ... the employment in practice of... specifically Parliamentary remedies has on occasion been perceived as falling short, and sometimes well short, of what was needed to bring the performance of the executive into line with the law and with the minimum standards of fairness implicit in every Parliamentary delegation of a decision-making function. To avoid a vacuum in which the citizen would be left without protection against a misuse of executive powers the courts have had no option but to occupy the dead ground in a manner, and in areas of public life, which could not have been foreseen 30 years ago". 67

Clearly, therefore, the potential exists for the courts to utilise the judicial review jurisdiction in such a way as to alleviate the lack of accountability which attaches

${ }^{63}$ Supra. $n .59$ at 417. Compare the approach of the Court of Appeal in $R v$ Secretary of State for the Home Department, ex parte Northumbria Police Authority [1988] 1 All E.R. 556, in which authority for the existence of a prerogative of "keeping the peace" was traced back to the Proclamation of Humbert Walter the Justiciar (1195) and the Statute of Winchester (1285) see Purchas L.J. at 566.

${ }^{64}$ Lord Irvine of Lairg QC, "Judges and Decision-Makers: The Theory and Practice of Wednesbury Review" [1996] P.L. 59.

${ }^{65}$ E.g. Sir J. Laws, "Judicial Remedies and the Constitution" (1994) 57 M.L.R. 223; Sir S. Sedley, "Governments, Constitutions and Judges" in G. Richardson and H. Genn (eds.), Administrative Law and Governmem Action (1994).

${ }^{66}$ See M. Radford, "Mitigating the Democratic Deficit? Judicial Review and Ministerial Accountability" in Leyland and Woods, supra. n.36; G. Ganz, "Criminal Injuries Compensation: the Constitutional Issue" (1996) 59 M.L.R 95.

${ }^{67} R v$ Secretary of State for the Home Department, ex parte Fire Brigades Union [1995] 2 All E.R. 244 at 268. 
to the exercise of prerogative powers, and by so doing, to render this area of executive action more modernised and transparent. Indeed, the increasingly interventionist approach of the courts in this context and elsewhere has led some to discern the emergence of a "surrogate political process" function for judicial review, in which individuals and groups dissatisfied with, or excluded from, conventional political channels, can articulate issues and concerns which are not otherwise addressed. ${ }^{69}$ If this assessment is accepted, judicial review would seem to represent a viable mechanism for "opening up" acts taken under the authority of the prerogative to scrutiny, debate and - to a limited extent - participation by the public $^{70}$ in a manner which is largely unachievable through the Parliamentary process.

Yet it is surely important not to overstate the capability of the courts to "democratise" and "modernise" the prerogative. While the familiar assessment of judicial review as "sporadic and peripheral" may now require qualification in the light of the considerable increase in its incidence in recent years, ${ }^{71}$ it remains the case that its contribution to the control of central government and the development of constitutional principle is necessarily limited by the relatively small number of cases which come to court. ${ }^{72}$ In the context of the prerogative, the role of judicial review is likely to be further restricted by the nature of the powers, which confer very general discretion upon ministers and which lack the "objectives" which can be discerned when a decision or action taken under statutory authority is challenged.

${ }^{68}$ The phrase is that of R. Stewart, "The Reformation of American Administrative Law", (1975) 88 Harvard Law Review 1667 at 1670.

${ }^{69}$ See particularly D. Oliver, "Underlying Values of Public Law" in M. Taggart (ed.), The Province of Administrative Law (1997), p.241: "the courts are taking on a role as a forum for political debate and settlement of disputes with a political dimension - a Grand Inquest of the Nation forum - in response to the increasingly obvious inability and unwillingness of the House of Commons to do so".

${ }^{70}$ For a discussion of the restricted role of judicial review in enhancing participation, see P. Craig, Public Low and Democracy in the United Kingdom and the United States of America (1990), pp.161-2.

7) See S. de Smith, H. Woolf and J. Jowell, Judicial Review of Administrative Action (5th ed., 1995), paras. 1-002 and 1-033.

${ }^{72}$ It is argued by L. Bridges, G. Meszaros and M. Sunkin (in Judicial Review in Perspective (1995), p.11) that "the volume of judicial review litigation is tiny by contrast to the scale of administrative decision making", with challenges to central government amounting to just over $25 \%$ of the total (ibid. p. 41 ). 


\section{PREROGATIVE POWERS AND NEW LABOUR}

The consequence of this is that it may be more difficult for the courts to justify intervention, particularly on grounds of "irrationality", 73 although it is clear from $e x$ parte Smith that this ground is available. ${ }^{74}$ It has also been argued that the absence of an underlying philosophy of administrative law and an overriding statement of individual rights to which the courts can have recourse in judicial review cases "has left our courts singularly ill-equipped to adjudicate effectively on the use of prerogative powers" ${ }^{75}$ In this context, the imminent incorporation of the European Convention on Human Rights into domestic law may offer a framework allowing a more coherent rationale for judicial intervention to be developed. ${ }^{76}$

The speech of Lord Mustill in the Fire Brigades Union case points to further difficulties entailed by the assumption of such a role by the courts, supplementing Labour's constitutional reform project. His Lordship stressed the need for sensitivity on the part of the "parliamentarian, administrator and judge if the delicate balance of the unwritten rules evolved... in recent years is not to be disturbed", 77 while Lord Irvine has similarly called for "judicial self-restraint" to be shown. ${ }^{78}$ These remarks clearly indicate the reluctance of the judiciary to violate the doctrine of the separation of powers, especially in areas which have a high policy content, as will be the case with many exercises of the prerogative ${ }^{79}$ They demonstrate a discomfort with the principle - upon which any judicial involvement in "modernising" the

${ }^{73}$ G.C.H.Q., supra. n.59 at 410-411 (Lord Diplock).

${ }^{74}$ Supra. n.60. The Court of Appeal found, however, that the threshold of irrationality had not been crossed in this case (see Sir Thomas Bingham M.R. at 266).

${ }^{75}$ Vincenzi, supra. n. 38, p.60.

${ }^{76}$ For a discussion of a "rights"-based approach to judicial review, see F. Donson, "Civil Liberties and Judicial Review: Can the Common Law Really Protect Rights?" in Leyland and Woods, supra. n.36.

${ }^{77}$ Supra. n. 67 at 268.

${ }^{78}$ Supra. n.64 at $75-8$.

${ }^{79}$ A number of executive functions under the prerogative have been held by the courts to be non-justiciable - see G.C.H.Q., supra. n.59 at 418 (Lord Roskill); ex parte Everett, supra. n. 60 at 820 (Taylor L.J.) - the effect being to preclude judicial intervention in these areas. However, in ex parte Smith [1995] 4 All E.R. 427 (Q.B.D.) at 446, Simon Brown L.J. stated that "only the rarest cases will today be ruled strictly beyond the court's purview"; although the greater the policy content of a decision, the more hesitant a court will be in holding it to be irrational - see supra. n.60 at 264 (Sir Thomas Bingham M.R.). 
prerogative would seem to depend - that the courts should strive to enhance the quality of democracy within the political system; an approach which is rendered highly problematic both by the lack of democratic legitimacy of an unelected judiciary and by unequal access to the judicial review process. ${ }^{80}$

\section{Reform of the prerogative}

For the reasons outlined above, it seems unlikely that Parliament will be in a position to reform the prerogative in the absence of government support for such a move; while the ability of the courts to do so is restricted and the constitutional appropriateness of such action highly questionable. Accordingly, it would appear that there is little chance of reform as long as the government remains uncommitted. However, speculation as to the possible fonn of any changes to prerogative powers remains a valuable exercise, not least because it is important to draw a distinction between proposals of a radical nature and those which are perhaps more readily achievable, should the Labour position on this issue alter.

Labour's unwillingness to reform the royal prerogative contrasts starkly with proposals advanced by the Liberal Democrats. This is of particular interest, given the co-operation between the two parties on constitutional matters, reflected in the establishment of a Joint Consultative Committee on Constitutional Reform prior to the election, ${ }^{81}$ and subsequent Liberal Democrat representation on the Cabinet subcommittee on the constitution. The party proposes a set of reforms which are radical in that the ultimate objective is the drawing up of a written constitution, which will come into effect following a referendum; however, as a preliminary step it is envisaged that a Reform Bill covering the "key issues of constitutional reform" will be enacted ${ }^{82}$ The Bill provides that certain defined areas of the royal prerogative the ratification of treaties, the dissolution of Parliament and the choice of the Prime

${ }^{80}$ See R. Cotterrell, “Judicial Review and Legal Theory” in Richardson and Genn, stupra. n.65, p. 18; LeSeuer and Sunkin, supra. n.53, p.481. Discussing the Fire Brigades Union case, Ganz concludes that "when the unelected judiciary feel obliged to repair the malfunctioning of the democratic process there is something badly wrong with the state of our democracy", supra. n.66 at 100.

${ }^{81}$ Supra. n. 5 .

${ }^{82}$ Liberal Democrats, The Reform Bill 1997. 


\section{PREROGATIVE POWERS AND NEW LABOUR}

Minister - shall be abolished and taken over by Parliament. ${ }^{83}$ Remaining areas of the prerogative will also be abolished, with "all executive powers [being] derived from the constitution or from laws passed by the appropriate legislature" ${ }^{84} \mathrm{O} \mathrm{th} \mathrm{e} \mathrm{r}$ proposals seeking to address the issue of prerogative powers also do so in the broader context of the creation of a written constitution. One of the most vociferous campaigners for the reform of the prerogative has been Tony Benn, for whom it is a necessary concomitant of republicanisation. On the basis that "the House of Commons is the only elected part of Parliament and democratic principles should require that all prerogative powers be controlled by that House", 85 Benn's Commonwealth of Britain Bill ${ }^{86}$ provided for the ending of the constitutional status of the Crown ${ }^{87}$ and the transfer of powers presently exercised under the authority of the prerogative to a President acting subsequent to a resolution of the House of Commons. ${ }^{88}$ The Bill offered a list of such powers, together with a "residual" provision allowing the President "to exercise other executive powers not conferred by statute", and required prerogative instruments of a legislative character to be brought in as Bills, with those of an administrative nature being laid before the House of Commons for approval. ${ }^{90}$

Similarly, the draft constitution produced by the Institute of Public Policy Research," while retaining the monarch as Head of State, established the constitution as the sole foundation for all executive power, thereby abolishing the residue of prerogative powers. ${ }^{92}$ Certain situations presently governed by the

${ }^{83}$ Clauses 3,5 and 6 respectively. Provision is made for a fixed Parliamentary term of four years (clause 4), but dissolution may also be voted for subsequent to a vote of no confidence.

${ }^{84}$ Liberal Democrats, Constitutional Declaration (1996), article 5(1).

${ }^{85}$ T. Benn and A. Hood, Common Sense (1993), pp.45-6.

${ }^{86}$ H.C. Bill 103 (1992-3). The Bill was not moved on Second Reading.

${ }^{87} \mathrm{Ibid}$. clause 37.

${ }^{88}$ Ibid. clauses 14 (1) (a) and (b).

${ }^{89}$ Ibid. clause 14 (1) (c).

${ }^{90} \mathrm{Ibid}$. clauses 14 (2) and (3).

${ }^{91}$ The Constitution of the United Kingdom (1991).

${ }^{92}$ Ibid. article 1. 
prerogative were defined and made subject to Parliamentary approval; ${ }^{93}$ while the government was given a residual executive power to act within the provisions of the constitution. ${ }^{94}$

It is, of course, inevitable that any programme of constitutional reform based around the creation of a written constitution would need to cater for the significant executive powers currently exercised by virtue of the prerogative and, given the "democratic deficit" previously identified, it is equally unsurprising that all of the projects outlined above envisage improved mechanisms of accountability, whether to Parliament or to the judicial organs entrusted with oversight of the constitution. However, it does not follow from this that reform of the prerogative can only be achieved within the framework of a written constitutional document. ${ }^{95}$ It would be perfectly possible to enact ordinary legislation covering such matters so that authorisation for executive activity in these areas derived from statute, rather than the common law; indeed, as Lord Browne-Wilkinson observed in the Fire Brigades Union case, "the constitutional history of this country is the history of the prerogative powers of the Crown being made subject to the overriding powers of the democratically elected legislature as the sovereign body". 96

Reform of this type would be of a gradual, "step by step" nature, with particular categories of prerogative power progressively receiving Parliamentary attention. In the present climate, the function most likely to be given statutory authorisation would appear to be regulation of the civil service, with future legislation in this field having been endorsed by the Joint Consultative Committee, ${ }^{97}$ and in the Commons by the Minister for Public Service. ${ }^{98}$ The proposed Civil Service Act would give statutory basis to the existing Civil Service Code and Orders in Council, and could

${ }^{93}$ E.g. treaty-making (article 51 ); declarations of war and the deployment of armed forces (articles 122 and 123); national security (article 126) and declarations of emergency (article 128).

${ }^{94}$ Ibid. article 40 .

95 A similar argument is advanced in the Demos pamphlet, supra. n.48, p.25, which observes that "the perceived difficulties associated with the drafting of a single written constitution should not serve as the pretext for avoiding the depoliticisation of the monarchy".

${ }^{96}$ Supra. n.67 at 254.

${ }^{97}$ Supra. n.5, para. 84

${ }^{98}$ Official Report (H.C.) 4 June 1997, vol. 295, col. 375. 
provide for the express abolition of the prerogative in this context. ${ }^{99}$

Other areas of the prerogative which could be relatively easily "translated" into statute might include the ratification of treaties, for which a model is already available in the form of Lord Lester's Treaties (Parliamentary Approval) Bill; ${ }^{100}$ and the issue of passports, particularly in view of the acknowledgment by the previous government that "refusal of passport facilities to United Kingdom nationals is confined to certain well defined categories... although the issue of passports is a discretionary power under the royal prerogative, it is as constrained as any statutory power might be". ${ }^{101}$ Situations where government may need to respond rapidly and flexibly to events, such as declaration of war" ${ }^{102}$ or the "prerogative of keeping the Queen's peace within the realm", ${ }^{103}$ present somewhat greater difficulty, especially since it is difficult to anticipate every eventuality which might arise, but could be addressed within statutes granting "the executive enhanced powers, broad discretion to act and respond to the exigencies of the situation and ability to legislate further". 104

Various objections might be raised to such a programme of reform. Perhaps the most familiar of these is based upon the impracticability of defining the precise scope and extent of the prerogative, given its residual nature, and the "complexity" of the relationship between statutory and prerogative powers. This has been used by ministers as a justification for refusing to enumerate the number of actions taken under its authority, and therefore implicitly to resist calls for reform. ${ }^{105}$ The argument

${ }^{99}$ FDA News (July 1997, p.2), quoted in K. Theakston, "New Labour, New Whitehall?" (1998) 13 Public Policy and Administration 13 at 24. For further discussion, see N. Lewis, "A Civil Service Act for the United Kingdom" [1998] P.L. 463.

${ }^{100}$ H.L. Bill 27 (1995-6).

${ }^{101}$ C. Wardle, Official Report (H.C.) 21 April 1993, vol. 223, col. 489. It should also be noted that Directive 68/360/EEC gives European Union citizens the right to be issued with an identity card or passport valid for travel through and between member states. p. 126.

${ }^{102}$ A prerogative power specifically pinpointed in Straw's call for reform, supra. n. 46,

${ }^{103}$ As in the Northumbria Police Authority case, supra. n.63.

${ }^{104}$ D. Bonner, Emergency Powers in Peacetime (1985), p. 10.

${ }^{105}$ See Official Report (H.C.) 21 April 1993, vol. 223, col. 490; personal communication by letter from Cabinet Office (12 March 1997); both citing A. Bradley and K. Ewing, Constitutional and Administrative Law (now 12th ed., 1997), p.274. 
which flows from this is that, because prerogative powers cannot easily be catalogued, "there is no sensible option of a blanket approach"106 which could catch all of the powers; and in view of this the status quo is preferable. It is submitted that this reasoning is disingenuous; as previously observed, there is no difficulty with isolating particular areas of the prerogative which might be the subject of legislative reform - problems of defining its overall scope should not be used to justify a refusal to address these functions. It is true that dealing with the "residue" of prerogative powers not otherwise given statutory basis is more problematic, but it should be possible to draft legislation abolishing all remaining royal prerogatives ${ }^{107}$ (without providing a list, which could prove incomplete and allow the prerogative to "resurface" in a particular area) and requiring government to derive legal authority for those acts and decisions not otherwise covered by statutory provision from such an Act. Although legislation of this type cannot be entrenched under present constitutional arrangements, political and public opinion is surely likely to render it all but immune from repeal.

Arguably, a more telling criticism of a project which seeks to give statutory basis to prerogative powers is that it will make little difference in practice to the manner in which those powers are exercised. On this analysis, the need to provide government with very wide discretionary powers, particularly in "emergency" situations, severely limits scrutiny of executive action, whether by Parliament or the courts. ${ }^{108}$ Moreover, Parliamentary oversight of ministerial activity, even under statutory authority, is likely to remain weak as long as executive dominance of the legislature persists. The grip of the executive needs to be loosened - either by means of electoral reform, to reduce the chance of one party holding an overwhelming

${ }^{106}$ Wardle, supra. n. 101, col. 492.

107 Express statutory abolition of the prerogative in the defined areas discussed above would also seem to be required, given the reluctance of the courts to hold that a power has been abolished by implication (see the Northumbria Police Authority case, supra. n. 63), coupled with the absence of a doctrine of extinction of such powers by long disuse: see Vincenzi, supra. n. 38, pp. 24-5.

${ }^{108}$ Indeed, it might be argued that the courts presently take a "harder look" at executive actions based upon ancient prerogatives than they would at those which might be taken under the authority of a broadly-worded modern-day statute, duly passed by a democratic legislature hence, statutory enactment might actually reduce the likelihood of successful challenge in judicial review. Such a view, however, would seem to underestimate the willingness of the courts to compensate for the inadequacies of Parliamentary scrutiny of executive activity, whatever its legal authority: see supra. n.64 and text. 
majority; or by reform of Parliament itself, especially the whip system.

Clearly, there is considerable validity in this critique; however, a number of points may be raised in response. Firstly, the enactment of legislation covering various areas of the prerogative would itself provide a valuable opportunity to examine and debate the nature and extent of the powers claimed by the executive. Secondly, any legislation so passed could contain provisions granting Parliament a greater degree of involvement in particular executive decisions and acts subsequently taken under its authority, perhaps on the model of the Treaties (Parliamentary Approval) Bill, which provided for affirmative resolution of each House of Parliament in particular circumstances, ${ }^{109}$ with negative procedure applicable in other cases. This would provide an opportunity for concerned MPs to require ministers to justify their actions, although in the absence of any reforms to strengthen the position and independence of the legislature, the likelihood of defeating the government must remain minimal. Finally, and most significantly, while placing these powers on a statutory footing might not necessarily render executive accountability to the courts or Parliament completely comprehensive, it would at least endow them with the democratic legitimacy which the royal prerogative lacks.

\section{Conclusion}

This last-mentioned factor alone would seem to be good enough reason for a government which is purportedly committed to democratisation and modernisation to grasp the nettle of reform of the prerogative. While total transparency, accountability and participation in respect of the exercise of these powers may remain elusive goals, legislative enactment - without the need to go as far as the drawing up of a written constitution, which is not part of the Blairite reform agenda offers the opportunity for a democratically-elected body to scrutinise and recast these ancient common law powers in a manner appropriate to the creation of a "constitution for the future, not the past". ${ }^{110}$ At present, however, there seems little sign that even a reform-minded executive is willing to abjure the considerable advantages it gains from the possession of vague, flexible and largely unaccountable prerogative powers.

${ }^{109}$ I.e. where treaties affect existing laws or private rights, affect the taxpayer or cede territory: supra n.100, clauses $3(1)$ and (2).

110 Joint Consultative Committee on Constitutional Reform, supra. N.5, para. 14. 